\title{
BAHASA TUBUH DALAM AL QUR'AN JUZ KE 30 (ANALISIS SEMANTIS)
}

\author{
Mintaraga Eman Surya \\ Fakultas Agama Islam Universitas Muhammadiyah Purwokerto, Email: \\ mintaragaesurya@gmail.com
}

\begin{abstract}
ABSTRAK
Al Qur'an sebagai mukjizat yang penuh dengan keistimewaan, kalimat-kalimatnya mampu mengeluarkan sesuatu yang abstrak kepada fenomena yang konkret, sehingga dapat dirasakan ruh dinamikanya, termasuk menundukkan seluruh kata dalam suatu bahasa untuk setiap makna dan imajinasi yang digambarkannya. Penelitian ini bertujuan untuk mengidentifikasi dan mendeskripsikan bentuk-bentuk, makna dan fungsi bahasa tubuh dalam Al-Qur'an juz ke 30 . Penelitian berjenis kepustakaan (library research), obyek utamanya adalah mushhaf al-Qur'an. Pendekatan utama yang digunakan adalah pendekatan ilmu tafsir dan ilmu komunikasi. Dalam menganalisis data tersebut digunakan metode deduktif, induktif dan komparasi. Penelitian ini memanfaatkan metode penelitian deskriptif yaitu metode yang bertujuan membuat deskripsi, maksudnya membuat gambaran, lukisan secara sistematis, faktual dan akurat mengenai data, sifatsifat serta hubungan fenomena-fenomena yang diteliti. Hasil dari penelitian ini bahwa Al Qur'an juz ke 30 mengungkap bahasa tubuh yang meliputi ekspresi wajah, bibir dan mulut, gerakan mata, dan gerakan badan. Dan menunjukkan keadaan dan kondisi kejiwaan seperti kesedihan, ketidaksukaan, penolakan, kemarahan, kekhawatiran, ketakutan ataupun kerelaan, ketenangan dan kegembiraan; menunjukkan makna perilaku visual yang tidak diinginkan bertujuan untuk mengejek dan menunjukkan perasaan tidak suka.
\end{abstract}

Kata Kunci: Al Qur'an; Bahasa Tubuh; Juz 30

\begin{abstract}
Al-Qur'an as a miracle full of privileges, its sentences are able to bring out something abstract to concrete phenomena so that its dynamic spirit can be felt, including subordinating all words in a language to each meaning and imagination it describes. This study aims to identify and describe the forms, meanings and functions of body language in the 30th Al-Qur'an juz. Research is a type of library research, the main object of which is the Al-Qur'an manuscripts. The main approach used is the approach of interpretation science and communication science. In analyzing the data, deductive, inductive and comparative methods are used. This study utilizes descriptive research methods, namely methods that aim to make descriptions, meaning to draw pictures, paintings systematically, factually and accurately regarding the data, characteristics and relationships of the phenomena under study. The result of this research is that the 30th Al Qur'an juz reveals body language which includes facial expressions, lips and mouth, eye movements, and body movements. And denotes mental states and conditions such as sadness, dislike, rejection, anger, worry, fear or willingness, calm and joy; showing the meaning of the unwanted visual behavior aims to mock and show feelings of dislike.
\end{abstract}

Keywords: Al Qur'an; Body Language; Juz 30 


\section{PENDAHULUAN}

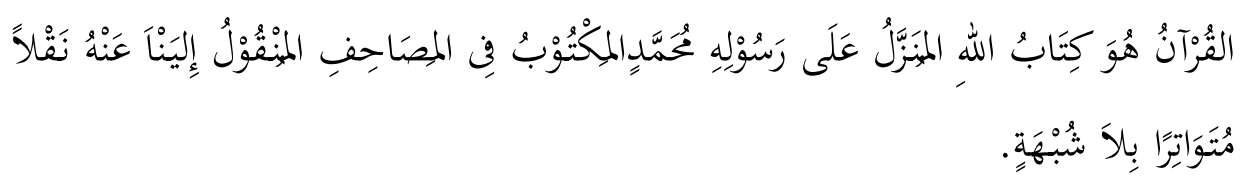

"Al-Qur'an adalah Kitab Allah yang diturunkan kepada Rasul-Nya Muhammad SAW, tertulis di lembaran-lembaran (telah dibukukan) dan sampai kepada kita secara mutawatir tanpa keraguan" (Zaidan, Abdul Karim, 1417-1996: 15).

Menurut Departemen Agama (sekarang Kementrian Agama), Al-Qur'an adalah kalamullah yang diturunkan kepada Nabi Muhammad SAW melalui Malaikat Jibril secara mutawatir serta membacanya adalah ibadah. Al-Quran merupakan penutup semua kitab yang diturunkan Allah dan diwahyukan kepada penutup semua Nabi, Al-Qur'an berisi ilmu pengetahuan, hukum-hukum, kisahkisah, falsafah, akhlak, peraturan-peraturan yang mengatur tingkah laku dan tata cara hidup manusia baik sebagai makhluk individual maupun sosial, serta menjadi petunjuk bagi penghuni langit dan bumi (Departemen Agama RI, 1990).

Dalam Manahilul 'Irfan, Az-Zarqani mengutip dari al-Baihaqy bahwa dalam proses penurunan Al-Qur'an Allah memperdengarkan dan memahamkan Al-Qur'an kepada Jibril. Yang dibawa turun oleh Jibril kepada Nabi SAW, adalah Al-Qur'an, dengan pengertian ia merupakan kata-kata haqiqi yang mengandung kemukjizatan dari awal surat al-Fatihah hingga surat An-Nas. Semua kata-kata itu adalah kalamullah. Jadi Jibril maupun Nabi tidak memiliki andil sama sekali dalam kemunculan maupun penyusunannya (Al-Zarqani, Muhammad Abdul Adzim, 2002).

Disimpulkan dari beberapa keterangan di atas bahwa Al-Qur'an merupakan wahyu Allah yang otentik diturunkan kepada Nabi Muhammad SAW lafdzan dan ma'nan, bukan karya manusia ataupun ada campur tangan manusia di dalamnya untuk petunjuk dan pedoman hidup umat manusia. Hal ini menjadi keyakinan kaum muslimin sejak berabad-abad yang lalu dan menjadi kesepakatan para ulama. Keyakinan ini merupakan bagian dari dasar keimanan seorang muslim dan tanpanya dia keluar dari sendi keimanan. Legalitas Allah ta'ala mengenai hal ini terdapat dalam beberapa ayat, diantaranya :

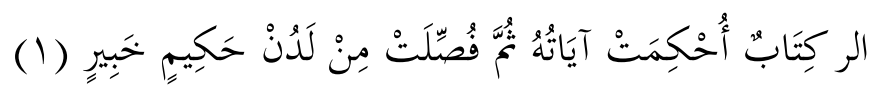

"Alif laam raa, (inilah) suatu kitab yang ayat-ayatNya disusun dengan rapi serta dijelaskan secara terperinci, yang diturunkan dari sisi (Allah) yang Maha Bijaksana lagi Maha Tahu” (QS. Hud: 1).

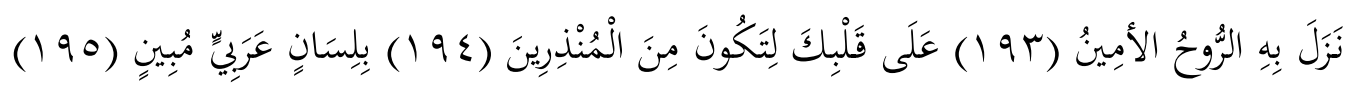


"Dia dibawa turun oleh Ar-Ruh Al-Amin (Jibril), ke dalam hatimu (Muhammad) agar kamu menjadi salah seorang di antara orang-orang yang memberi peringatan, dengan bahasa Arab yang jelas" (QS. Asy-Syu'araa': 193-195).

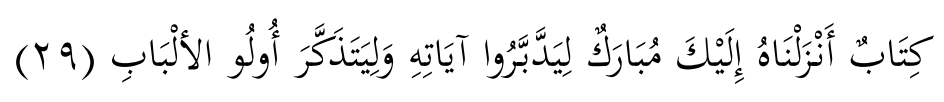

"Ini adalah sebuah kitab yang Kami turunkan kepadamu penuh dengan berkah supaya mereka memperhatikan ayat-ayatNya dan supaya mendapat pelajaran orang-orang yang mempunyai fikiran" (QS. Shad: 29).

Al Qur'an sebagai mukjizat yang penuh dengan keistimewaan, Said Aqil menjelaskan sebagai berikut:

1. Kelembutan Al-Qur`an secara lafziyah yang terdapat dalam susunan suara dan keindahan bahasa.

2. Keserasian Al-Qur`an baik untuk orang awam maupun cendekiawan.

3. Sesuai dengan akal dan perasaan, yakni Al-Qur’an memberi doktrin pada akal dan hati, serta merangkum kebenaran serta keindahan sekaligus.

4. Keindahan sajian serta susunannya, seolah-olah suatu bingkai yang dapat memukau akal dan memusatkan tanggapan dan perhatian.

5. Keindahan dalam liku-liku ucapan atau kalimat serta beraneka ragam dalam bentuknya.

6. Mencakup dan memenuhi persyaratan global (ijmaly) dan terperinci (tafsily).

7. Dapat memahami dengan melihat yang tersurat dan tersirat (Munawar, 2002).

Al-Qur`an dari segi kebahasaan dan kesastraannya mempunyai gaya bahasa yang khas yang sangat berbeda dengan bahasa masyarakat Arab, baik dari pemilihan huruf dan kalimat yang keduanya mempunyai makna yang dalam. Usman bin Jinni (932-1002 H) seorang pakar bahasa Arab sebagaimana dituturkan Quraish Shihab mengatakan bahwa pemilihan kosa kata dalam bahasa Arab bukanlah suatu kebetulan, melainkan mempunyai nilai falsafah bahasa yang tinggi (Shihab, 1999). Kalimat-kalimat dalam Al-Qur`an mampu mengeluarkan sesuatu yang abstrak kepada fenomena yang konkret sehingga dapat dirasakan ruh dinamikanya, termasuk menundukkan seluruh kata dalam suatu bahasa untuk setiap makna dan imajinasi yang digambarkannya. Kehalusan bahasa dan uslub Al-Qur`an yang menakjubkan terlihat dari balaghah dan fashahah-nya, baik yang konkret maupun abstrak dalam mengekspresikan dan mengeksplorasi makna yang dituju sehingga dapat komunikatif antara Autor (Allah) dan penikmat (umat) (Munawar, 2002).

Dari pemilihan kata dan kalimat, Al-Qur’an mempunyai sinonim dan homonim yang sangat beragam, contohnya kata yang berkaitan dengan perasaan cinta diungkapkan saat bertatap pandang atau mendengar kabar yang menyenangkan, kemudian jika sudah ada perasaan untuk bertemu dan mendekat menggunakan ميل, seterusnya bila sudah ada keinginan untuk menguasai dan 
memiliki dengan ungkapan مودة, tingkat berikutnya محبة, dilanjutkan dengan خلة, lalu الهوى , dan bila sudah muncul pengorbanan meskipun membahayakan diri sendiri namanya العشق, bila kadar cinta telah memenuhi ruang hidupnya dan tidak ada yang lain maka menjadi التتيم, yang semua itu bila berujung pada tarap tidak mampu mengendalikan diri, membedakan sesuatu maka disebut وليه (Shihab, 1999: 97). Semua kata-kata tersebut mempunyai porsi dan efek makna masingmasing. Demikian juga dalam pengungkapan bahasa tubuh manusia sebagai bagian dari komunikasi yang terdapat dalam surat-surat dan ayat-ayatnya. Secara tersurat Al Qur'an menjelaskan tentang fungsi bahasa tubuh atau tanda-tanda dari tubuh yang dapat dikenali orang lain dalam surat Muhammad (47) ayat ke 30 :

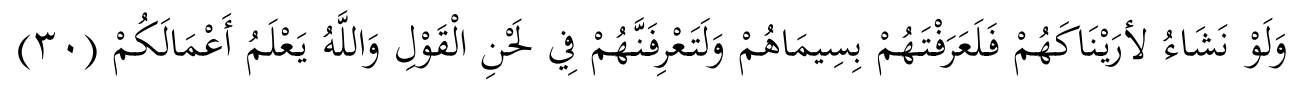

"Dan kalau Kami kehendaki, niscaya Kami tunjukkan mereka kepadamu sehingga kamu benar-benar dapat mengenal mereka dengan tanda-tandanya. dan kamu benar-benar akan mengenal mereka dari kiasan-kiasan perkataan mereka dan Allah mengetahui perbuatan-perbuatan kamu”.

Komunikasi adalah proses berbagi makna melalui perilaku verbal dan nonverbal. Komunikasi terjadi jika setidaknya suatu sumber membangkitkan respons pada penerima melalui penyampaian suatu pesan dalam bentuk simbol (adalah kata, jargon, isyarat, gambar, gaya atau obyek (simbol status) yang mengandung makna tertentu yang hanya dikenali oleh mereka yang menganut suatu budaya) atau tanda (Tanda lebih luas daripada simbol, karena mencakup juga indeks atau gejala yang mewakili sesuatu lainnya secara alamiah atau ditandai dengan hubungan sebab akibat misalnya uban sebagai tanda menua atau meringis sebagai tanda sakit (Geert Hofstede dalam Mulyana, 2005: 3-4), baik bentuk verbal atau bentuk nonverbal.

Dalam kehidupan sosial, manusia tidak hanya menggunakan bahasa verbal, tetapi juga bahasa tubuh (nonverbal) dalam melakukan komunikasi. Setiap kali bicara dengan orang lain, dari tutur kata yang terucap biasanya dibarengi dengan gerak-gerik kecil dari tubuh baik gerakan mata, perubahan sikap tubuh, tangan ataupun ekspresi wajah. Gerakan-gerakan tubuh dalam berkomunikasi ini dapat disadari oleh penutur atau pelakunya ataupun tidak. Biasanya, dalam berlangsungnya bahasa tubuh menggunakan sekaligus kedua-duanya yaitu bahasa verbal dan bahasa nonverbal. Misalnya seseorang berkeluh kesah tentang orang lain, "Saya tidak tahu bagaimana saya mengetahuinya, tetapi saya yakin bahwa ia tidak menyukai saya". Ini menunjukkan tidak hanya perasaan yang diekspresikan secara verbal namun gerakan tubuh, perilaku mata dapat memberi penafsiran atau mengukuhkan rasa tidak suka tersebut. Hal tersebut menunjukkan bahwa pesan- 
pesan komunikasi tidak hanya dialihkan secara verbal saja, tetapi juga dengan menggunakan bahasa isyarat, gerakan-gerakan anggota tubuh, tangan, wajah, mata dan jari-jemari. Semua gerakan itu mempunyai makna tertentu. Aspek bahasa tubuh seperti ini disebut Kinesics.

Istilah ini (Kinesics) pertama kali dikumandangkan oleh seorang peneliti dari Amerika Ray Birdwhistell yang merupakan salah satu dari generasi pertama yang melakukan kajian tentang komunikasi gerak tubuh ketika mulai terjadi ketertarikan yang besar terhadap kajian ini pada akhir tahun 1940-an. Kine adalah bagian terkecil yang dapat diamati dari gerakan tubuh dan kinesics ini merujuk pada kajian ilmiah tentang gerak-gerik dan gerakan tubuh lainnya (Wainwright, 2007).

Secara umum, bahasa tubuh dapat digunakan untuk mendukung dan memberikan tekanan terhadap apa yang dikatakan, menunjang emosi yang ingin diekpresikan bahkan untuk menyembunyikan perasaan hatinya atau sebagai sarana untuk mendapatkan pemahaman lebih baik terhadap sesuatu yang sedang dikomunikasikan orang lain. Bahasa tubuh mempunyai peranan pada pengembangan pribadi dan penggalian pada daya manusia bahkan mampu membangun hubungan-hubungan sinergis -yaitu hubungan yang membawa hasil lebih besar dari jumlah masukan individu- bersama dengan perannya dalam membangun hubungan, empati dan rasa kebersamaan (Wainwright, 2007).

Zakii (2001:24-25) menyebutkan berbagai istilah yang dipakai para ahli untuk bahasa nonverbal, seperti gesture language/ لغة الإشارة (Critchley,1939), bodily (Blake, 1933), bodily communication التعبير الجسمى / expression (Argyle, 1975), body language لغة الجسمى (Julus Fast, 1983; Albert \& Scheflen, 1972) dan silent language اللغة الصامتة/ (Hall, 1955; Critchley, 1955). Untuk konsistensi penyebutan dalam penelitian ini akan digunakan istilah bahasa tubuh.

Bahasa tubuh meliputi ekspresi wajah, nada suara, gerakan anggota tubuh, kontak mata, rancangan ruang, pola-pola perabaan, gerakan ekspresif, perbedaan budaya dan tindakan-tindakan nonverbal lain yang tidak menggunakan kata-kata. Edward T. Hall dan Birdwhistell (Trager dalam Little John, 1978) menggolongkan bahasa tubuh ini menjadi tiga jenis umum, yaitu :

1. Kinesic, yaitu kajian mengenai gerak-gerik tubuh meliputi kepala, ekspresi wajah, mata, mulut, tangan, tubuh dan kaki.

2. Procsemic, yaitu kajian mengenai penggunaan jarak ketika berkomunikasi.

3. Paralanguage, yaitu kajian mengenai komunikasi suara nonverbal yang memakai variasi vokal dan variasi itu memiliki makna yang berbeda-beda tergantung pada kebudayaannya. 
Larry A. Samovar dan Richard E. Porter membagi bahasa tubuh menjadi dua kategori, yaitu: perilaku yang terdiri dari penampilan dan pakaian, gerakan dan postur tubuh, ekspresi wajah, kontak mata, sentuhan, bau-bauan dan parabahasa; dan ruang, waktu dan diam. Dalam beberapa puluh tahun terakhir ini sudah banyak penelitian dilakukan terhadap komunikasi nonverbal, selanjutnya disebut bahasa tubuh, dari berbagai tinjauan disiplin ilmu seperti psikologi, sosiologi, antropologi dan linguistik yang mempelajari aspek tingkah laku manusia yang muncul dan memiliki fungsi komunikatif. Kemudian dari hasil kajian-kajian dan penelitianpenelitian tersebut muncul cabang-cabang ilmu baru, seperti kinesika yang mengkaji tentang komunikasi dan bahasa tubuh; proksemika tentang kajian jarak antarindividu; dan parabahasa yang mengkaji tentang komunikasi suara non-verbal.

Studi tentang ekspresi nonverbal atau bahasa tubuh ini mempunyai sejarah yang panjang, setidaknya sejak Charles Darwin menjadikannya sebagai salah satu obyek penyelidikan dalam ekspedisinya yang terkenal itu. Bahasa tubuh ini mulamula berawal dari ekspresi wajah (Argyle,1998: Shimoda, Argyle dan RicciBitti,1978). Darwin, yang pada awalnya tertarik pada ekspresi wajah sebagai petunjuk emosi itu yakin bahwa gerakan-gerakan ekspresi wajah dan tubuh merupakan suatu pernyataan yang sangat penting (Liliweri, 2002). Ekman (1972) setuju dengan pendapat Darwin bahwa ekspresi-ekspresi wajah dan tubuh sebagai reaksi emosional yang spontan itu, selain dipengaruhi oleh faktor bawaan, juga dipengaruhi oleh faktor-faktor eksternal.

Pada awalnya para ahli syaraf dan psikologi memandang bahwa isyaratisyarat itu hanya digerakkan oleh perintah otak karena gerakan-gerakan itu hanya merupakan refleks semata (2002:189). Ternyata dalam perkembangan selanjutnya, isyarat-isyarat itu menjadi kaya makna dan semua gerakan itu dilakukan di bawah sadar dan terkontrol. Dalam perkembangannya, dugaan Darwin itu benar karena bahasa isyarat yang ditemukan di semua suku bangsa di muka bumi ini berkaitan erat dengan simbol-simbol komunikasi, sedangkan bahasa verbal merupakan sesuatu yang spesifik yang berkaitan dengan kebudayaan para pemakainya, hal ini karena simbol-simbol yang diucapkan melalui kata-kata diketahui oleh mereka yang menggunakannya. Beberapa dekade sepeninggal Darwin, beberapa peneliti kemudian melakukan pembaruan atas asumsi Darwin tersebut dan melakukan pengukuran yang lebih metodologis terhadap bahasa tubuh (R.Rosenthal, P.Backlund, M.Redmond dan A.Barbour, 1979). Edward T. Hall (1979) akhirnya menyusun sebuah buku berjudul Handbook for Procsemic Research tentang proksemik yang menerangkan penggunaan jarak dalam berkomunikasi.

Desmond Morris (Wainwright, 2007) adalah seorang penulis populer di bidang bahasa tubuh. Dia dan sebuah tim peneliti dari Universitas Oxford menerbitkan panduan mengenai asal-usul dan penggunaan 20 macam gerak-gerik. Dari informasi yang dikumpulkan melalui 40 tempat di Eropa, mereka berhasil 
mengidentifikasi seberapa sering masing-masing gerak-gerik muncul dan apa makna yang terkandung di dalamnya. Penemuan mereka mengindikasikan seberapa pentingnya memperhitungkan kemunculan tersebut untuk mengetahui konteks dimana gerak-gerik digunakan sebelum menginterpretasikan maknanya. Mereka juga memperlihatkan bahwa suatu gerak-gerik bisa memiliki makna yang berlawanan di bagian Eropa yang satu dengan bagian Eropa lainnya. Dari 20 macam gerak-gerik, ditemukan 5 gerak-gerik universal yang mempunyai makna dan penggunaan yang hampir sama.

Eckard Hess (Wainwright, 2007) dalam bukunya The Tell-Tale Eye yang memuat hasil penelitiannya, menyatakan bahwa ketika kita melihat sesuatu yang menarik maka bola mata kita akan membesar. Dalam eksperimennya Hess memperlihatkan pada orang-orang satu set gambar yang terdiri atas lima lembar gambar; seorang bayi, seorang ibu dan bayi, laki-laki telanjang, perempuan telanjang dan sebuah pemandangan alam. Dia mengukur respons bola mata terhadap gambar-gambar itu dan menemukan bahwa bola mata laki-laki paling lebar saat melihat perempuan telanjang (kecuali homoseksual maka sebaliknya). Mata perempuan melebar saat melihat laki-laki telanjang tetapi lebih lebar saat melihat gambar ibu dan bayi. Penelitian-penelitiannya ini memperlihatkan bahwa perubahan-perubahan bola mata ini terjadi selaras dengan ketertarikan orang-orang tersebut pada berbagai gambar.

Argyle (Wainwright, 2007) mengklasifikasikan bahasa tubuh dalam kategori tertentu dengan mengemukakan lima perbedaan fungsi yang dapat diwakili oleh gerak-gerik atau bahasa tubuh, yaitu sebagai berikut :

1. Ilustrasi dan isyarat-isyarat penghubung bicara lainnya

2. Isyarat-isyarat konvensional dan bahasa isyarat

3. Gerakan mengekspresikan emosi

4. Gerakan mengekspresikan kepribadian

5. Gerakan yang digunakan dalam berbagai kegiatan keagamaan dan ritual lainnya.

Menurut Simon Capper (1997), bahasa tubuh berfungsi sebagai berikut ini:

1. Fungsi regulasi yaitu menjelaskan bahwa simbol non verbal yang digunakan mengisyaratkan proses komunikasi verbal sudah berakhir. Fungsi ini bermanfaat untuk mengatur bahasa tubuh secara seksama untuk menyakinkan orang lain dalam menginterpretasi makna yang disampaikan secara verbal.

2. Fungsi interpersonal. Fungsi ini membantu untuk menyatakan sikap dan emosi dalam relasi antarpribadi. Beberapa penelitian yang berkaitan dengan pertukaran nonverbal menunjukan bahwa ada sinkronisasi, kongruensi dan konvergensi yang dapat ditunjukan oleh bahasa tubuh (wallbott, 1995). Ditemukan bahwa bahasa tubuh dapat meningkatkan relasi yang sangat tinggi antara para peserta komunikasi, misalnya meningkatkan simpati atau daya tarik kepada lawan bicara. 
3. Fungsi emblematis, yaitu menerangkan bahwa bahasa tubuh dapat disampaikan melalui isyarat-isyarat gerakan anggota tubuh, terutama tangan. Seperti ketika seseorang mengacungkan ibu jarinya menghadap ke atas yang berarti menunjukan rasa puas atau bagus.

4. Fungsi ilustratif. Fungsi menerangkan bahwa bahasa tubuh digunakan untuk mengidentifikasi ukuran, bentuk dan jarak.

5. Fungsi adaptasi. Fungsi adaptasi dimaksudkan sebagai fungsi bahasa tubuh untuk menyesuaikan pelbagai pesan baik verbal maupun nonverbal. Gerakangerakan reflek seperti memegang-megang jenggot, mengurai rambut mengusap wajah dan sebagainya termasuk dalam kategori ini.

Berkaitan dengan fungsi bahasa tubuh terhadap komunikasi verbal Liliweri (2002) menambahkan sebagai berikut :

1. Fungsi mengulang. Bahasa tubuh berfungsi untuk mengulangi apa yang sudah dikatakan secara verbal.

2. Fungsi menyisip atau menyela. Hal ini dilakukan manakala seseorang menampilkan simbol non verbal untuk mengganti simbol verbal. Seperti ketika seseorang menginterupsi suatu pembicaraan dengan mengacungkan telapak tangannya ke atas.

3. Fungsi melengkapi, yaitu bahasa tubuh melengkapi makna yang sudah dinyatakan secara verbal.

4. Fungsi menekankan. Fungsi ini kadang disebut accenting-calling. Berfungsi memberi tekanan pada apa yang sudah dikatakan secara verbal. Ketika seseorang merasa tidak mengerti, tidak percaya atau heran dengan apa yang terjadi, seseorang tersebut mengerutkan dahi dan memukulkan telapak tangan lengkap dengan kelima jarinya ke dahi.

5. Fungsi mempertentangkan. Bahwa bahasa tubuh ini berfungsi mempertentangkan pesan-pesan yang telah disampaikan secara verbal ataupun nonverbal.

Paul Ekman dan Wallace Friesen (1969) juga mengemukakan secara lebih rinci bahwa ada 5 kelompok pesan yang bisa diwakili oleh gerak-gerik atau teori fungsional dalam kategori sebagai berikut :

1. Emblem atau perlambang yaitu gerakan yang mewakili kata-kata. Emblem digunakan secara intensif untuk mengirimkan sebuah pesan tertentu kepada penerima dan dapat digunakan bersamaan dengan waktu pengucapan kata-kata verbal. Ada 3 bentuk umum emblem, yaitu:

a. Emblem merupakan terjemahan langsung dari pesan verbal

b. Emblem diketahui oleh sebagian besar anggota suatu kelompok sosial

c. Emblem mempunyai pengaruh dan dampak tertentu pada penerimanya. 
Ada banyak isyarat yang memakai emblem yang harus diterjemahkan dengan baik karena dalam proses komunikasi ada perbedaan budaya antarbangsa. Menunjukan ibu jari dalam banyak negara dan tempat bisa berarti "bagus", di Eropa bisa berarti "tergantung anda" dan di Jawa bisa berarti "silahkan" atau untuk menunjukan arah tertentu.

2. Ilustrator atau gerakan yang menyertai bicara. Seseorang ketika berbicara kadang membuat ilustrasi dengan gerakan tangan dan jari-jarinya tentang jarak suatu tempat, melukiskan ukuran suatu benda dan sebagainya. Ada 3 fungsi ilustrator, yaitu (a) menerjemahkan pesan yang sulit, (b) melukiskan sebuah materi kepada pendengar, dan (c) membantu penerima agar lebih mudah menerjemahkan sebuah pesan.

3. Regulator atau gerakan yang mengisyaratkan perubahan pada saat orang sedang mendengarkan atau berbicara. Gerakan ini untuk mendukung interaksi dan komunikasi antara pengirim dan penerima. Hal ini berfungsi untuk memberi keyakinan pada orang lain bahwa apa yang disampaikan adalah hal yang sangat penting.

4. Adaptor adalah bahasa tubuh untuk mengungkapkan perasaan kecemasan, seperti gerakan menggaruk-garuk kepala, menggosok-gosokkan tangan atau gerakan tanpa arah yang menghindari silau cahaya, seperti pada seseorang yang dalam kondisi emosi. Gerakan ini lebih banyak diapandang sebgai gerakan reflek atau kebiasaan. Adaptor terdiri dari 2 bentuk, yaitu (1) terfokus pada tubuh, seperti menggaruk; (2) terfokus pada obyek, seperti merokok. Beberapa teori yang berkaitan dengan adaptor sebagai berikut :

a. Adaptor merupakan isyarat yang mempertimbangkan kesepakatan bersama, namun isyarat itu kemudian berubah menjadi kebiasaan atau refleks.

b. Adaptor berkaitan dengan perasaan yang negatif, seperti kecemasan.

c. Isyarat-isyarat untuk mewakili sesuatu yang tidak tentu, baik yang terfokus pada organ tubuh maupun pada obyek, selalu dikaitkan dengan tipe informasi dan tipe kemampuan pendengar.

5. Affect Display atau merefleksikan perasaan yang sedang dialami. Bentuk ini menunjukan sejauhmana perasaan atau tekanan batin yang dialami melalui kombinasi ekspresi wajah dan gerakan tubuh (Liliweri, 2002).

Sementara itu, studi tentang bahasa tubuh (gesture) dan fungsinya dalam komunikasi di kalangan ilmuwan humaniora Arab masih belum mendapat perhatian yang serius (Zaki, 2001). Terdapat karya klasik linguis Arab semisal Al-Jaachidz yang telah membahas kajian alat-alat komunikasi dalam bab "Al-Lafdz walisyaarah wal-'aqd wal-khath wan-nashab" di buku "Al-Bayaan wat-Tabyiin". Demikian pula, ilmuwan Arab lainnya telah mengkaji peran bahasa tubuh dalam komunikasi, seperti Ibnu Jinny, Ibnu Rasyiiq dan Abu Ischaaq Asy-Syairazy. Tetapi bahasan mereka belum mendalam dan menyentuh aspek-aspek kebudayaan tertentu 
baik dalam hubungannya dengan budaya, kejiwaan ataupun menjelaskan pola-pola dan bentuk-bentuk tertentu.

Terdapat pula kajian ringkas dalam bentuk makalah di majalah dan jurnal, seperti karya Faathimah Machjuub tentang "Al-charakah Al-Jismiyah Fil-Qur'an" (Gerakan/bahasa tubuh dalam Al Quran) di majalah Minbar Al-Islaam edisi 7 Rajab 1394 H/ Juli 1974 dan Ad-dilaalaah al-charakiyah lil-alfaadz fii sy-syi'r (Kata-kata yang menunjukan bahasa gerak dalam syair) dalam majalah Asy-syi'r edisi bulan Oktober 1978. Kariim Zakii Chusaam Ad-Diin (2001) dalam bukunya Al-Isyaaraat Al-Jismiyah terbitan Dar Al-Ghariib Kairo juga membahas bahasa tubuh, hanya saja pembahasannya lebih banyak menjelaskan teori-teori barat dan mengungkap teoriteori dari linguis Arab klasik serta mengkaji bahasa tubuh dalam Al-Qur'an, AlHadits dan syair-syair.

\section{METODE PENELITIAN}

Artikel ini merupakan berasal dari penelitian kepustakaan (library research), karena sumber datanya adalah berupa teks, baik al-Qur'an maupun buku-buku karya para ahli ilmu tafsir dan komunikasi, bahasa yang berbicara tentang bahasa tubuh dalam al-Qur'an. Karena penelitian ini fokusnya adalah ayat-ayat yang mengandung bahasa tubuh dalam al-Qur'an yang ditafsirkan dengan pendekatan ilmu tafsir dan semantic kinestetis, maka obyek utamanya adalah mushhaf alQur'an. Mushhaf yang digunakan adalah al-Qur'an al-Karim bi ar-Rasm alUtsmani. Terjemahan al-Qur'an yang digunakan adalah terjemahan Departemen Agama RI, kecuali di beberapa tempat dikombinasikan dengan terjemahan yang ada dalam The Holy Qur'an. Adapun sumber-sumber buku lain, khususnya yang terkait dengan tafsir dan bahasa tubuh .Al-Jami' li Ahkâm al-Qur'ân (Al-Qurtubi, Abu Abdullah Muhammad bin Ahmad al-Ansari, 1967), al-Khasysyaf 'an Haqâiq atTanzil wa 'Uyun al-Aqâwil fi Wujûh at-Ta'wîl (Al-Zamakhsyari, Abu Qasim Jarullah Mahmud Ibn Umar, 1977), Tafsîr al-Qur'ân Al-Azîm (Kasir, Ibnu:1986), Al-Isyaaraat Al-Jismiyah (Zaki, Kariim Chusaam Ad-Diin. 2001), 'Ilmu Al-Lugah Al-'Ijtimaa'i. ( As-Sayyid, Shabrii Ibrahim: 1995), Al-'Ibaarah wa Al-Isyaarah (Al'Abd, Muhammad: 2007), Ad-Dilaalah wa Al-Harakah (Dawud, Muhammad Mahmud: 2002), Bodily Communication (Argyle, M.Bodily: 1998), Nonverbal Communication and the Second Language (Capper, Simon: 1997), , Komunikasi Antar Manusia (DeVito, Joseph A.: 1997), Makna Budaya Dalam Komunikasi Antar Budaya (Liliweri, Alo M.S.: 2002), Ilmu Komunikasi; Suatu Pengantar (Mulyana, Deddy : 2002), Komunikasi Antar Budaya (Mulyana, Deddy dan Jalaluddin Rahmat. 1989), Komunikasi Efektif; Suatu Pendekatan Lintas Budaya (Deddy: 2005), Understanding Intercultural Communication (Samovar,et.al. 1981), Membaca Bahasa Tubuh (Wainwright, Gordon R.: 2007), , Verbal and Nonverbal Communication of Deception dalam Advances in Experimental Social Psychology (Zuckerman, DePaulo dan Rosenthal. 1981), Nonverbal Communication and the 
Second Language (Capper, Simon. 1997) dan Nonverbal Communication in Human Interaction (Knapp, M.L. tt).

Mengingat obyek penelitian ini adalah ayat-ayat al-Qur'an, maka pendekatan utama yang digunakan adalah pendekatan ilmu tafsir dan ilmu komunikasi. Dalam penelitian ini kedua metode itu akan digunakan dalam membahas ayat-ayat alQur'an karena relevan dengan topik penelitian. Dalam menganalis data tersebut juga digunakan metode deduktif, induktif dan komparasi. Metode deduktif digunakan untuk menganalisis data yang bersifat umum lalu prinsip-prinsip tersebut diterapkan pada persoalan-persoalan yang lebih khusus. Adapun metode induktif digunakan untuk menganalisis persoalan-persoalan khusus lalu merangkainya menjadi prinsip-prinsip yang bersifat umum. Metode komparasi digunakan untuk membandingkan antara berbagai data sehingga dapat diambil satu kesimpulan yang tepat pada satu persoalan. Penelitian ini memanfaatkan metode penelitian deskriptif yaitu metode yang bertujuan membuat deskripsi, maksudnya membuat gambaran, lukisan secara sistematis, faktual dan akurat mengenai data, sifat-sifat serta hubungan fenomena-fenomena yang diteliti (Djajasudarma, 2006).

\section{HASIL DAN PEMBAHASAN}

Hybels dan Weafer II mengatakan bahwa komunikasi adalah setiap proses pertukaran informasi, gagasan, dan perasaan. Proses itu meliputi informasi yang disampaikan tidak hanya secara lisan dan tulisan, tetapi juga dengan bahasa tubuh, gaya maupun penampilan diri atau menggunakan alat bantu di sekeliling manusia untuk memperkaya sebuah pesan (Hybels dan Weafer II, 1992: 6 dalam Liliweri, 2002). Gerard Nierenberg dan Henry Calero (Wainwright, 2007) mengemukakan bahwa gerak-gerik tubuh digunakan untuk mengekspresikan berbagai hal di antaranya: keterbukaan, sikap bertahan, kesiapan, menenteramkan hati, frustasi, keyakinan diri, kegelisahan, penerimaan, pengharapan, hubungan dan kecurigaan. Gerak-gerik tetap digunakan meskipun dalam situasi di mana lawan bicaranya tidak terlihat, seperti ketika sedang melakukan komunikasi melalui telepon.

Secara umum, bahasa tubuh dapat digunakan untuk mendukung dan memberikan tekanan terhadap apa yang dikatakan, menunjang emosi yang ingin diekspresikan bahkan untuk menyembunyikan perasaan hatinya atau sebagai sarana untuk mendapatkan pemahaman lebih baik terhadap sesuatu yang sedang dikomunikasikan orang lain (Wainwright, 2007).

Dalam penelitian ini, penulis hanya membatasi kajian seputar Kinesics, yaitu mengenai gerak-gerik tubuh meliputi kepala, mata, mulut, ekspresi wajah, bahu, tangan, tubuh dan kaki yang mempunyai makna serta fungsi tertentu dalam Al Qur'an juz ke 30. Informasi-informasi dan data-data awal dalam penelitian ini diperoleh melalui pencarian ayat-ayat dalam Al Qur'an juz ke 30 yang menunjukkan makna baik tersurat ataupun tersirat mengenai bahasa tubuh berupa 
gerakan tubuh yang meliputi mata, mulut, kepala, bahu, tangan, tubuh, kaki, ekspresi wajah maupun bahasa verbal yang bermanfaat dalam pengklasifikasian, pendeskripsian bentuk, makna dan fungsinya. Peneliti kemudian mengklasifikasikan data-data yang diperoleh berupa bahasa tubuh sesuai dengan anggota tubuh yang dominan digunakan menjadi bahasa tubuh yang berupa ekspresi wajah, mulut, gerakan mata, gerakan tangan, dan gerakan Badan. Setelah melalui proses pengklasifikasian bahasa tubuh kemudian peneliti mendeskripsikan gerakangerakan atau bahasa tubuh tersebut, menjelaskan bentuk dan makna.

\section{Ekspresi Wajah, Bibir dan Mulut}

Wajah manusia ternyata menyimpan banyak sekali misteri. Para ahli psikologi menyebut wajah dan ekspresinya sebagai the organ of emotion. Karena tanda-tanda yang ada di wajah berkaitan dengan perasaan manusia dan tandatanda itu dapat diinterpretasi oleh orang lain di sekeliling kita. Wajah manusia selalu menampilkan dinamika, menunjukkan identitas dan menggambarkan usia. Oleh karena itu, wajah merupakan kekuatan saluran komunikasi nonverbal yang diterjemahkan atau diencode oleh pengirim dan kemudian didecode oleh penerima dengan makna yang berlaku dalam suatu konteks sosial atau budaya tertentu. Informasi tentang kondisi emosional seseorang dapat diperoleh melalui ekspresi-ekspresi wajahnya. Kondisi emosional ini dapat terbaca dengan jelas melalui ekspresi-ekspresi wajahnya apakah menunjukan rasa senang atau tidak, tertarik atau bosan dan takut atau marah.

Wajah digunakan untuk memperlihatkan keberuntungan individu, mengekspresikan kondisi perasaan pada waktu tertentu, menunjukkan sejauhmana perhatian pada seseorang dan sebagainya. Senyuman dapat menunjukan rasa senang dan ketertarikan dan mengerutkan dahi bisa menunjukkan sebaliknya. Memandang ke bawah bisa menunjukan ketidakbahagiaan, memiringkan kepala ke salah satu sisi menunjukkan sedang mendengarkan dan sebagainya.

Dua peneliti Amerika, Paul Ekman dan Wallace Friesen (Wainwright, 1995) menemukan bahwa ada enam prinsip ekspresi wajah yang digunakan untuk menunjukkan perasaan ketika orang sedang merasa bahagia, sedih, jijik, marah, takut dan tertarik. Mereka menemukan bahwa hanya perasaan inilah yang dapat diketahui secara pasti maknanya ketika melihat orang mengekspresikannya pada mereka. Sylvan S. Tomkins (1962) dan Carrol Izard (1977) juga menemukan setidaknya ada 8 dasar emosi wajah yang mencengangkan, yaitu emosi yang menyatakan surprise, minat, gembira, gusar, takut, jijik atau muak, malu dan kesedihan yang mendalam.

Senyuman merupakan ekspresi wajah yang penggunaannya paling universal dan bentuk ekspresi wajah yang paling positif. Senyuman digunakan di 
seluruh dunia untuk menunjukkan atau mencerminkan rasa senang atau bahagia, ketentraman hati, kegembiraan bahkan ejekan. Senyuman juga dapat digunakan untuk menyembunyikan perasaan-perasaan yang lain (Wainwright, 2007). Senyum biasanya digunakan sebagai gerak-gerik mengucapkan salam dan umumnya diindikasikan untuk berbagai tingkat kesenangan, kegembiraan dan kebahagiaan walaupun dalam konteks tertentu dapat diartikan sebagai sikap menyerang, sindiran tajam dan perasaan-perasaan negatif lain. David B. Givens dalam bukunya Center for Nonverbal Studies (1998-2001) mengemukakan bahwa senyuman dapat menunjukkan pesan bahwa orang yang merasa bersalah biasanya menampilkan senyum masam melalui sedikit kuluman bibir diiringi dengan wajah yang muram serta mata menunjukkan rasa malu.

Kebalikan dari wilayah emosional di atas adalah kesedihan, tidak ada ekspresi tertentu yang dapat mewakilinya secara pasti. Kesedihan, kekecewaan dan depresi biasanya ditunjukkan dengan tanpa ekspresi senyum, dengan gerak gerik seperti melengkungkan ke bawah sudut bibir, menunduk dan umumnya roman muka terlihat mengerut. Kesedihan yang sangat akan dicirikan dengan meneteskan air mata, bibir gemetar dan berusaha menutupi wajahnya. Muak dan jijik ditunjukkan dengan menyipitkan mata dan mulut menyeringai, yang menjadi lebih terungkapkan dengan peningkatan kekuatan perasaan itu. Hidung juga akan berkerut dan kepala ditolehkan ke samping untuk menghindari melihat penyebab reaksi.

Marah umumnya dicirikan dengan tatapan kuat pada sumber yang membuat sakit hati, mengerutkan dahi atau muka yang cemberut dan gerakan gigi secara bersama-sama. Pada beberapa orang wajahnya menjadi pucat, tetapi pada beberapa yang lain terlihat memerah ketika sedang sangat marah atau mengamuk. Seluruh badannya menjadi tegang seperti bersiap diri ingin segera menyerang atau menyakiti. Kekhawatiran atau ketakutan juga memiliki tidak hanya satu ekspresi saja. Perasaan ini ditunjukkan dengan mata terbuka lebar, mulut membuka atau tubuh bergetar yang mempengaruhi wajahnya serta seluruh tubuhnya. Bahkan mungkin ditandai dengan keluarnya keringat dan warna pucat pada wajahnya.

Ketertarikan seringkali ditunjukkan dengan istilah menelengkan kepala, yaitu mempertahankan posisi kepala pada suatu sudut dengan pandangan mengarah pada obyek yang menarik perhatiannya. Atau ditunjukkan dengan mata terbuka lebih lebar dan mulut sedikit terbuka, ketika duduk dagu disangga dengan jari-jarinya sambil mendengarkan atau memperhatikan dengan penuh (Wainwright, 2007). Wajah, bibir dan mulut dalam Al Qur'an juga digunakan untuk menunjukkan keadaan dan kondisi kejiwaan seperti kesedihan, ketidaksukaan, penolakan, kemarahan, kekhawatiran, ketakutan ataupun kerelaan, ketenangan dan kegembiraan (Al Abd, 2007). 
a. Digunakan untuk menunjukkan keadaan dan kondisi kejiwaan seperti kesedihan, ketidaksukaan, penolakan, kemarahan, kekhawatiran dan ketakutan.

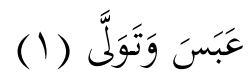

“Dia (Muhammad) bermuka masam dan berpaling” (QS. Abasa: 1).

Kesedihan hati dan dukacita yang muncul dari terasa sempitnya dada adalah makna yang dikenal secara umum dari kata " " ${ }^{66}$ tetapi diayat ini menunjukkan ketidaksukaan yang menjadikannya sedih.

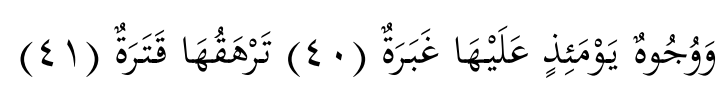

"Dan banyak (pula) muka pada hari itu tertutup debu. Dan ditutup lagi oleh kegelapan” (QS. Abasa: 40-41).

Maksudnya mereka ditimpa kehinaan dan kesusahan. Ayat tersebut menggambarkan tentang perubahan ekspresi wajah karena kesedihan dan dukacita dengan kata "غَبَرَ" yang berarti hal yang berhubungan dengan debu

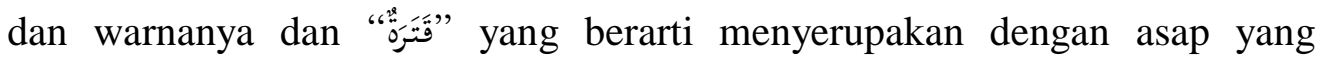
menutupi wajah dari kebohongan. Kedua perumpamaan tersebut menunjukkan makna keadaan jiwa yang berada dalam kesedihan dan keadaan hati dalam kemaksiatan ( $\mathrm{Al} \mathrm{Abd,} \mathrm{2007).}$

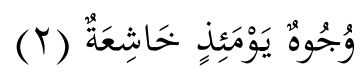

"Banyak muka pada hari itu tunduk terhina”. (QS. Al Ghaasyiyah: 2).

Maknanya adalah wajah-wajah yang terhina dan rendah karena siksa yang menantinya (ibid, 1996, 20: 19)

Demikian juga dengan gerak bibir dan suara yang keluar dari bibir, seperti ayat berikut :

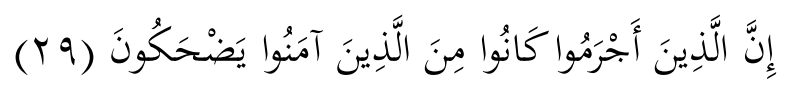

"Sesungguhnya orang-orang yang berdosa, adalah mereka yang menertawakan orang-orang yang beriman”. (QS. Al Muthaffifin: 29).

Menertawakan dengan maksud mengejek, menghina dan merendahkan. (Az Zuhaily, 2000)

$$
\text { فَالْيَوْمَ الَّذِينَ آمَنُوا ِمنَ الْكُفَّارِ يَضْحَكُونَ (ع) }
$$

Maka pada hari ini, orang-orang yang beriman menertawakan orang-orang kafir (QS. Al Muthaffifin: 34). 
Menertawakan dengan maksud mengejek karena melihat orang-orang kafir terhina dan terbelenggu di neraka (Az Zuhaily, 2000).

b. Digunakan untuk menunjukkan keadaan dan kondisi kejiwaan berupa kerelaan, ketenangan dan kegembiraan.

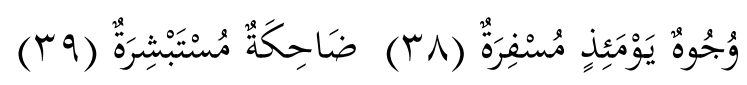

Banyak muka pada hari itu berseri-seri, tertawa dan bergembira ria. (QS. Abasa: 38-39)

Maknanya adalah kegembiraan terwujud dalam ekspresi wajah yang

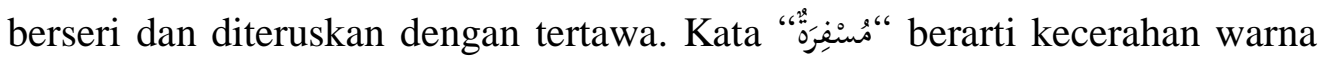
wajah karena gembira (Ibid, 2007: 161) atau Cerah bersinar karena mengetahui apa yang akan didapat berupa kemenangan dan kenikmatan, yaitu wajahnya orang-orang yang beriman (Al Qurtuby, 1996).

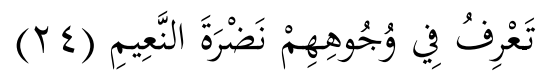

Kamu dapat mengetahui dari wajah mereka kesenangan mereka yang penuh kenikmatan (QS. Al Muthaffifin: 24).

Maknanya adalah kegembiraan, kenikmatan dan cahayanya. (ibid, 1996: 173) Mereka terlihat tanda-tanda kenikmatan, kepuasan, kebahagiaan dan kegembiraan dari wajahnya yang memancarkan cahaya, kebaikan dan keputih-putihan. (Az Zuhaily, 2000).

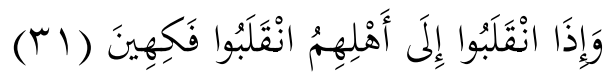

Dan apabila orang-orang yang berdosa itu kembali kepada kaumnya, mereka kembali dengan gembira (QS. Al Muthaffifin: 31).

Maknanya adalah gembira dengan membanggakan kekafirannya dan memfitnah orang-orang yang beriman. (Al Qurthuby, 1996).

$$
\text { وَيَنْقَلِبُ إِلَ أَهْلِهِ مَسْرُورًا (9) }
$$

Dan Dia akan kembali kepada kaumnya (yang sama-sama beriman) dengan gembira. (QS. Al Insyiqaaq: 9).

Maknanya adalah perasaan hati yang berbahagia (ibid, 1996: 19, 179)

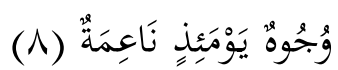

Banyak muka pada hari itu berseri-seri (QS. Al Ghasyiyah: 8).

Maknanya adalah wajah mereka pada hari Kiamat penuh keceriaan, kenikmatan, kebahagiaan dan kebaikan (Az Zuhaily, 2000). 


\section{Gerakan Mata}

Mata merupakan sarana yang paling utama dari bahasa tubuh. Dari observasi puitik Ben Jonsen's "Drink to me only with thine eyes and I will pledge with mine" sampai ke observasi ilmiahnya para periset kontemporer semisal Hess (1975) dan Marshall (1983), mata dipandang sebagai sistem bahasa tubuh yang paling penting.

Para peneliti dan penulis tentang bahasa tubuh mengungkapkan beberapa kemungkinan mengapa mata memiliki kekuatan yang besar dalam komunikasi ini. Ada yang mengemukakan bahwa, sejak masih bayi kita melihat mata orang lain sebagai dorongan yang kuat sehingga tertarik untuk memandangnya dan bahkan akan memberi respons yang sama terhadap segala sesuatu yang bulat seperti mata karena melalui matalah pertama kali kontak dilakukan dengan orang lain. Ada pula yang mengatakan bahwa respon kita terhadap kontak mata adalah bersifat instingtif dan berhubungan dengan pola-pola dasar kehidupan, dan pada anak-anak yang bisa mendapatkan dan mempertahankan kontak mata, seperti layaknya perhatian terhadap pemuasan kebutuhan mereka atas makan dan kebutuhan lainnya. Peneliti lain mengemukakan signifikansi dari kontak mata dipelajari, sebagaimana kita tumbuh, kita belajar untuk tidak bertingkah laku salah tatkala orang dewasa sedang memperhatikan kita, atau kita belajar bahwa cara tatapan tertentu dapat memberitahukan kepada kita apakah seseorang menyukai atau tidak (Wainwright, 2007).

Pesan-pesan yang dikomunikasikan oleh mata bervariasi bergantung pada durasi, arah dan kualitas dari perilaku mata. Arah pandangan mata juga mengkomunikasikan sesuatu. Tingkat kekonsistenan arah pandangan mata dapat mengkomunikasikan minat yang besar atau rendah, sadar-diri, tingkat emosi dan sebagainya. Lebar sempit terbukanya mata juga bisa mengkomunikasikan makna baik tingkat minat maupun emosi seperti keterkejutan, ketakutan dan kesebalan. Mark Knapp (1978) mengemukakan empat fungsi utama komunikasi mata, yaitu sebagai berikut ini (DeVito, 1997):

a. Mencari umpan balik. Mata seringkali digunakan untuk mencari umpan balik dari orang lain dalam komunikasi. Ketika sedang berbicara dengan orang lain dan untuk mendapatkan respon atau pendapatnya seringkali dengan tatapan mata yang sungguh-sungguh. Pendengar memandang pembicara lebih banyak ketimbang pembicara memandang pendengar. Argyle (1988) dan Knapp (1978) mengungkapkan bahwa waktu interaksi yang digunakan untuk memandang sambil mendengarkan adalah antara 62-75 persen. Sedangkan waktu yang digunakan untuk memandang sambil berbicara adalah antara 3841 persen.

b. Menginformasikan pihak lain untuk berbicara. Ketika seseorang bertanya kemudian menatap orang lain sebagai lawan bicaranya, tanpa berkata sepatah 
katapun orang yang ditatap dapat memahami bahwa dia diminta menjawab pertanyaannya.

c. Mengisyaratkan sifat hubungan. Hubungan yang positif antara dua orang ditandai dengan pandangan terfokus yang penuh perhatian dan sebaliknya hubungan yang negatif ditandai dengan penghindaran kontak mata.

d. Mengkompensasi bertambahnya jarak fisik. Dengan melakukan kontak mata seseorang secara psikologis dapat mengatasi jarak fisik yang memisahkannya dengan orang lain.

Argyle dan Mark Cook dalam bukunya Gaze and Mutual Gaze, Cambridge University Press membicarakan dengan detail tentang kontak mata, bentukbentuk dan fungsi atau makna yang dikandungnya. Menurutnya bentuk-bentuk kontak mata yang utama diantaranya adalah memalingkan kontak mata dengan mengalihkan arah tatapan ke bawah biasanya dianggap sebagai isyarat orang yang bersikap pasrah atau tunduk (Wainwright, 2007).

Wenburg dan Wilmot (1973) membagi fungsi kontak mata dalam komunikasi antarpribadi menjadi dua, yaitu: pertama, fungsi pengatur, untuk memberi tahu orang lain apakah akan melakukan hubungan atau menghindarinya; kedua, fungsi ekspresif, memberi tahu orang lain bagaimana perasaannya (Mulyana, 2002). Bahasa mata dalam Al Qur'an menunjukkan makna sebagai berikut :

a. Perilaku visual yang tidak diinginkan bertujuan untuk mengejek dan menunjukkan perasaan tidak suka, seperti “يَتََغَامَزُونَ" yang berarti mengedipngedipkan mata. Asal maknanya adalah isyarat dengan kelopak mata yang bertujuan mencari cacat, mengejek dan menghina. (Al Abd, 2007: 162; Az Zuhaily, 2000)

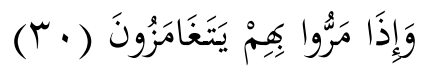

"Dan apabila orang-orang yang beriman lalu di hadapan mereka, mereka saling mengedip-ngedipkan matanya”. (QS. Al Muthaffifin: 30).

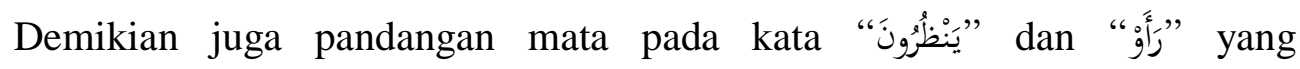
menunjukan pandangan mengejek dan menunjukkan perasaan tidak suka :

$$
\text { عَلَى الأرَائِكِ يَنْظُوُونَ (TT) }
$$

"Mereka (duduk) di atas dipan-dipan sambil memandang”.(QS. Al Muthaffifin: 23 dan 35).

$$
\text { وَإِذَا رَأَوْهُمْ قَالُوا إِنَّ هَوُلاءٍِ لَضَالُّونَ (Yr) }
$$


Dan apabila mereka melihat orang-orang mukmin, mereka mengatakan: "Sesungguhnya mereka itu benar-benar orang-orang yang sesat" (QS. Al Muthaffifin: 32)

b. Gerakan mata, arah pandangan dan ukuran terbukanya menunjukkan tanda-

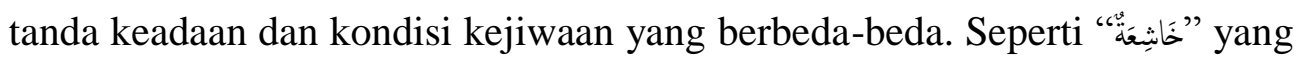
berarti tunduk karena takut.

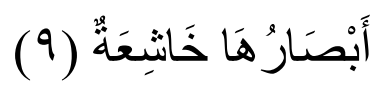

"Pandangannya tunduk “. (QS. An Naazi'at: 9).

Maknanya adalah pandangannya jatuh terhina karena ketakutan (Ibid, 1996; Az Zuhaily, 2000).

\section{Gerakan Badan}

Gerakan badan tertentu baik gerakan ringan dari tubuh ataupun gerakan gabungan antara tubuh dan anggotanya ternyata menunjukkan keadaan dan kondisi jiwa dan hati pelakunya. Di dalam Al Qur'an gerakan tersebut menunjukkan sikap menentang seperti :

$$
\text { تُمُ أَدْبَرَ يَسْعَى (Y) }
$$

"Kemudian Dia berpaling seraya berusaha menantang (Musa)" (QS. An Naazi'at: 22).

Makna ayat ini adalah berpaling membelakangi menentang keimanan dan ketaatan (Ibid, 1996, 19: 131; Az Zuhaily, 2000)

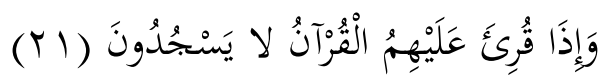

"Dan apabila Al Quran dibacakan kepada mereka, mereka tidak bersujud”. (QS. Al Insyiqaaq: 21).

Maknanya mereka tidak taat dan mengamalkannya (ibid, 1996). Sedangkan yang menunjukkan ketidaksukaan :

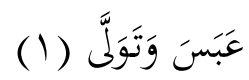

“Dia (Muhammad) bermuka masam dan berpaling” (QS. Abasa: 1).

\section{SIMPULAN}

Berdasarkan hasil penelitian yang penulis lakukan dapat disimpulkan hal-hal sebagai berikut ini, yaitu :

1. Al Qur'an sebagai mukjizat yang penuh dengan keistimewaan, kalimatkalimatnya mampu mengeluarkan sesuatu yang abstrak kepada fenomena yang konkret sehingga dapat dirasakan ruh dinamikanya, termasuk menundukkan seluruh kata dalam suatu bahasa untuk setiap makna dan imajinasi yang digambarkannya. Kehalusan bahasa dan uslubnya yang menakjubkan terlihat 
dari balaghah dan fashahahnya, baik yang konkret maupun abstrak dalam mengekspresikan dan mengeksplorasi makna yang dituju sehingga dapat komunikatif antara Autor (Allah) dan penikmat (umat).

2. Al Qur'an juz ke 30 mengungkap bahasa tubuh manusia sebagai bagian dari komunikasi yang terdapat dalam surat-surat dan ayat-ayatnya. Secara tersurat Al Qur'an menjelaskan tentang fungsi bahasa tubuh atau tanda-tanda dari tubuh yang dapat dikenali orang lain.

3. Bahasa tubuh dalam Al Qur'an juz ke 30 hanya meliputi ekspresi wajah, bibir dan mulut, gerakan mata, dan gerakan badan.

4. Wajah, bibir dan mulut dalam Al Qur'an digunakan untuk menunjukkan keadaan dan kondisi kejiwaan seperti kesedihan, ketidaksukaan, penolakan, kemarahan, kekhawatiran, ketakutan ataupun kerelaan, ketenangan dan kegembiraan.

5. Bahasa mata dalam Al Qur'an menunjukkan makna perilaku visual yang tidak diinginkan bertujuan untuk mengejek dan menunjukkan perasaan tidak suka; Gerakan mata, arah pandangan dan ukuran terbukanya menunjukkan tanda-tanda keadaan dan kondisi kejiwaan yang berbeda-beda.

6. Gerakan badan tertentu baik gerakan ringan dari tubuh ataupun gerakan gabungan antara tubuh dan anggotanya ternyata menunjukkan keadaan dan kondisi jiwa dan hati pelakunya yang gerakan tersebut menunjukkan sikap menentang dan ketidaksukaan.

\section{DAFTAR PUSTAKA}

Al-Zarqani, Muhammad Abdul Adzim, 2002. Manahilul 'Urfan Fi 'Ulum AlQur'an, GMP.

Arikunto, Suharsimi, 1998. Prosedur Penelitian : Suatu Pendekatan. Jakarta: Rineka Cipta.

Argyle, M.Bodily. 1998. Bodily Communication. New York: Methuen \& Company

As-Sayyid, Shabrì Ibrāhīm. 1995. 'Ilmu Al-Lugah Al-'Ijtimā̄i. Iskandariah: Dār Al-Ma'rifah Al-Jāmi'iyah

Al'Abd, Muhammad.2007. Al- 'Ibārah wa Al-Isyārah. Kairo: Maktabah Al-Ādāb

Capper, Simon. 1997. Nonverbal Communication and the Second Language

Dāwud, Muhammad Mahmūd, 2002. Ad-Dilālāh wa Al-Harakah. Kairo: Dār AlGarib

Departemen Agama RI, 1990, Al Qur'an dan terjemahannya

Djajasudarma, T. Fatimah. 2006. Metode Linguistik-Ancangan Metoda Penelitian dan Kajian. cet. 2. Bandung: PT. REfika Aditama

Dexter, Janet, 1995, Nonverbal Expressiveness: Relationship to a Chosen, Missouri: Major Western State College 
Dewan Redaksi Ensiklopedi Islam. 1997. Ensiklopedi Islam. cet. 4. Jakarta; Ichtiar Baru Van Hoeve

DeVito, Joseph A. 1997. Komunikasi Antar Manusia. terj. Agus Maulana MSM. Ed.V, Jakarta: Professional Books

Gudykunst, W.B. 1991. Bridging Differences-Effective Intergroup Communication. London: Sage Publication

Hall, E.T. 1979. Handbook for Proxemic Research.

Haviland, John B. 1996. "Pointing, Gesture Space and Mental” dalam Language \& Culture. Symposium.

Kinayati Djojosuroto \& M.L.A. Sumaryati. 2004. Prinsip-prinsip Dasar dalam Penelitian Bahasa dan Sastra. cet.2. Ed. Revisi. Bandung: Nuansa

Knapp, M.L. Nonverbal Communication in Human Interaction, New York: Holt, Rinehart, and Winston

Learner. Some Pedagogic Considerations. Hiroshima: Suzugamine Women's College

Littlejohn, Stephen W. 1999. Theories of Human Communication (6 $6^{\text {th }}$ edition). California: Belmont.

Liliweri, Alo M.S. 2002. Makna Budaya Dalam Komunikasi Antar Budaya. Cet.II. Yogyakarta: LKis.

Lubis, Lusiana Andriani Dra. MA. 2002. Penerapan Komunikasi Lintas Budaya di antara Perbedaan Kebudayaan. Fakultas Ilmu Sosial dan Ilmu Politik Jurusan Ilmu Komunikasi. Universitas Sumatera Utara

M.Amirin, Tatang. 1995. Menyusun Rencana Penelitian, Jakarta: Rajawali Pers

McLuhan, Marshall. 1964. Understanding Media: the Extensions of man. New York

Mehrabian, Albert N. 1972. Nonverbal Communication. Chicago: Aldine- Atherton

Mulyana, Deddy. 2002. Ilmu Komunikasi; Suatu Pengantar. Cet.IV. Bandung: PT Remaja Rosdakarya.

Mulyana, Deddy dan Jalaluddin Rahmat. 1989. Komunikasi Antar Budaya. Remaja Rosdakarya. Bandung.

Mulyana, Deddy. 2005. Komunikasi Efektif; Suatu Pendekatan Lintas Budaya. Cet.II. Bandung: PT Remaja Rosdakarya.

Munawar, Said Aqil, 2002, Al-Quran Membangun Tradisi Kesalehan Hakiki, Ciputat Press Jakarta, Cetakan ke 2 Agustus

Moleong, Lexy J. 2001. Metodologi Penelitian Kualitatif. Bandung: Remaja Rosdakarya

Pattilima, Hamid. 2007. Metode Penelitian Kualitatif. Bandung: Alfabeta, cv 
Petunjuk Penulisan Usulan Penelitian dan Tesis. 2002. Program Pascasarjana Universitas Gadjah Mada Yogyakarta

Qulyubi, Shihabuddin, 1997 Stilistika Al-Quran, Titan Ilahi Pers yogyakarta cetakan 1 November

Rakhman, Maman. 1992. Strategi dan Langkah-langkah Penelitian. Semarang : IKIP Semarang Press.

Samovar,et.al. 1981. Understanding Intercultural Communication. Belmont, California : Wodsworth Publishing Company.

Shihab, M. Quraish, 1999 Mukjizat Al-Quran, Misan Bandung, cetakan V April

Sudjana, Nana. 1997. Tuntunan Penyusunan Karya Ilmiah. Bandung: Sinar Baru Algesindo

Sugiyono. 2008. Metode Penelitian kuantitatif, Kualitatif dan $R \&$ D. cet. 4. Bandung: Alfabeta

Yusup, Suhendra. 1996. Communication MKDU Bahasa Inggris. Jakarta; PT. Gramedia Pustaka Utama

Wainwright, Gordon R.. 2007. Membaca Bahasa Tubuh. cet. 2. terj. Narulita Yusron. Yogyakarta; Baca.

Zaidan, Abdul Karim; Al Madkhol lidirasah Asy-Syariah Al-Islamiyah, Beirut: Muassasah ar-Risalah, 1417-1996

Zaki, Karīm̄ Chusām Ad-Dīn. 2001. Al-Isyārāt Al-Jismiyah. Kairo: Dar Al-Garīb

Zuckerman, DePaulo dan Rosenthal. 1981. Verbal and Nonverbal Communication of Deception dalam Advances in Experimental Social Psychology 14.

Al-Qurtubi, Abu Abdullah Muhammad bin Ahmad al-Ansari, 1967, .Al-Jami' li Ahkâm al-Qur'ân, Kairo, Dâr Al-Katib Al- Arabi

Al-Zamakhsyari, Abu Qasim Jarullah Mahmud Ibn Umar, 1977, .al-Khasysyaf 'an Haqâiq at-Tanzil wa 'Uyun al-Aqâwil fi Wujûh at-Ta'wîl, Beirut, Dâr al-Fikr

Kasir, Ibnu,1986, Tafsîr al-Qur'ân Al-Azîm, Beirut: Dar al-Fikr

Faathimah Machjuub, 1974, "Al-charakah Al-Jismiyah Fil-Qur'an" (Gerakan/bahasa tubuh dalam Al Quran), majalah Minbar Al-Islaam edisi 7 Rajab 1394 H/ Juli 1974

1978, Ad-dilaalaah al-charakiyah lil-alfaadz fii sy-syi'r (Kata-kata yang menunjukan bahasa gerak dalam syair), majalah Asy-syi'r edisi bulan Oktober 1978. 